\title{
Pengembangan Media Layanan Informasi Menghadapi Perubahan Masa Pubertas bagi Siswa Sekolah Dasar
}

\author{
Fitri Firdayati, Ella Faridati Zen, Elia Flurentin \\ Jurusan Bimbingan dan Konseling-Fakultas Ilmu Pendidikan-Universitas Negeri Malang- \\ Jl.Semarang No. 5, Malang, Jawa Timur 65145 \\ E-mail: fitrifirdayati@gmail.com
}

Artikel diterima: 5 September 2016; direvisi 4 November 2016; disetujui: 4 November 2016

\begin{abstract}
Abstrak: Penelitian ini bertujuan untuk menghasilkan produk berupa media layanan informasi "menghadapi perubahan masa pubertas" bagi siswa SD. Metode penelitian yang digunakan adalah penelitian dan pengembangan yang diadaptasi dari model pengembangan Borg and Gall dengan prosedur sebagai berikut: (1) perencanaan; (2) pengembangan produk; (3) uji coba produk; (4) revisi akhir produk. Data uji coba produk dianalisis secara kuantitatif dan kualitatif. Berdasarkan hasil penilaian uji coba produk dapat disimpulkan bahwa produk sangat tepat, sangat berguna, sangat mudah dan sangat menarik secara teoritis dan praktis, sehingga dapat digunakan sebagai media dalam bimbingan menghadapi perubahan masa pubertas.
\end{abstract}

Kata kunci: pengembangan media; layanan informasi; masa pubertas; siswa SD

Masa pubertas merupakan masa yang dialami oleh setiap individu. Masa puber adalah masa ketika terjadi kematangan alat-alat reproduksi dan tercapai kemampuan reproduksi. Saat masa puber berlangsung setiap individu mengalami perubahan dalam dirinya. Menurut Dumbar (dalam Janiwarty, 2013), selama masa pubertas akan terjadi banyak perubahan, di antaranya perubahan pada bentuk tubuh, penampilan diri, sikap kepemilikan, sikap sosial dan minat seks.

Setiap perubahan dalam diri individu memberikan dampak bagi dirinya. Hurlock (1980) menjelaskan bahwa dampak masa puber adalah adanya perubahan sikap dan perilaku pada diri individu. Dampak buruk dapat muncul seperti munculnya sikap keraguan dalam bertingkah laku, perasaan tidak mampu menyelesaikan tugas dan tidak aman dalam situasi lingkungan sosial.

Kurangnya penerimaan terhadap perubahan yang terjadi pada diri dapat membuat individu menutup diri terhadap lingkungan serta merasa malu dan memicu kecemasan. Selain itu, kurangnya pengetahuan dan persiapan tentang masa pubertas dapat membuat individu panik, takut dan malu. Hal ini penting untuk diperhatikan oleh institusi pendidikan yang dapat berperan dalam memberikan informasi berkaitan dengan perubahan masa pubertas.

Dijelaskan dalam Permendikbud RI nomor 111 Tahun 2014 bahwa Bimbingan dan Konseling memiliki peranan memberikan layanan bantuan yang bersifat psiko-edukatif kepada peserta didik (siswa) dalam upaya mencapai tugas-tugas perkembangannya secara optimal. Hal ini sesuai dengan permasalahan yang timbul berkaitan dengan perubahan yang terjadi pada masa pubertas. Layanan yang dapat diberikan dapat berupa layanan informasi.

Nurihsan (2006) menjelaskan layanan informasi adalah layanan yang memberikan informasi yang dibutuhkan oleh individu. Layanan informasi secara tidak langsung dapat memberikan tindakan pencegahan (preventif) terhadap masalah yang dialami oleh siswa. Layanan informasi yang diberikan juga dapat menambah wawasan siswa dalam proses pemahaman terhadap dirinya.

Pemberian layanan informasi kepada siswa dapat memanfaatkan media pendukung. Salah satu media pendukung yang dapat dikembangkan berupa media cetak. Media cetak yang 
dikembangkan hendaknya bersifat praktis dan dapat dibawa kemanapun. Media cetak yang dikembangkan berupa buku kecil berukuran setengah kertas kuarto yang didalamnya berisikan tulisan dan gambar.

Hurlock (1980) menjelaskan rentang usia masa pubertas berkisar 11-15 tahun untuk anak perempuan dan 12-16 tahun untuk anak laki-laki. Rentang usia ini merupakan rentang masa akhir kanak-kanak dan dimana jika usia sekolah memasuki usia sekolah dasar tepatnya masuk pada kelas tinggi tingkat sekolah dasar. Hal ini yang mendorong munculnya pengembangan media layanan informasi "menghadapi perubahan masa pubertas" dikembangkan bagi siswa sekolah dasar yang dapat berterima secara teoritis dan praktis.

\section{METODE}

Penelitian dan pengembangan ini menggunakan metode yang dikembangkan oleh Borg and Gall (1989), selanjutnya pengembang mengadaptasi langkah dari Borg and Gall yang terangkum dalam empat tahap. Tahap I perencanaan, melakukan study literature dan need asessment; tahap II pengembangan produk, merumuskan tujuan pengembangan, menyusun prototipe produk dan menyusun alat evaluasi produk; tahap III uji coba produk, melakukan uji ahli (materi dan media), revisi produk hasil penilaian uji ahli, kemudian uji calon pengguna produk dan uji kelompok kecil; tahap IV revisi produk akhir, yaitu produk dilakukan revisi berdasarkan masukan dari calon pengguna produk dan kelompok kecil.

Pada tahap awal penelitian dilakukan analisis kebutuhan. Analisis kebutuhan (need asessment) merupakan kegiatan pengumpulan data kebutuhan untuk dijadikan referensi agar produk yang dibuat sesuai dengan kondisi yang ada. Analisis kebutuhan dilakukan menggunakan metode wawancara dan angket kebutuhan siswa. Pada tahap kedua berdasarkan hasil analisis kebutuhan, pengembang mulai merancang prototipe produk. Setelah produk pengembangan dihasilkan, kemudian dilakukan uji coba produk. Uji coba produk dilakukan oleh ahli materi Bimbingan dan Konseling, ahli media pembelajaran, calon pengguna produk (guru kelas) dan siswa. Masukan dan saran pada uji coba produk digunakan sebagai dasar untuk merevisi produk, sehingga produk berterima secara teoritis dan praktis.

Teknik analisis data uji coba produk pada penelitian pengembangan ini menggunakan analisis data kuantitatif dan analisis data kualitatif. Analisis data kuantitatif digunakan untuk menganalisis data hasil penilaian pada format uji dengan menggunakan teknik kesepakatan atau inter-rateragreement. Analisis data kualitatif digunakan untuk menganalisis pendapat, masukan dan saran yang diberikan terhadap produk.

\section{HASIL}

Produk yang dihasilkan dalam penelitian dan pengembangan ini adalah media layanan informasi "menghadapi perubahan masa pubertas", yang berupa buku materi dan panduan pelaksanaan layanan bimbingan. Buku materi menghadapi perubahan masa pubertas terdiri atas dua jenis yaitu buku untuk anak perempuan dan untuk anak laki-laki. Terdapat 3 bagian sub materi dalam buku untuk anak perempuan yaitu (1) apa itu pubertas?; (2) apa haid atau menstruasi itu?; (3) dampak apa yang muncul ketika masa pubertas?. Hampir sama dengan buku untuk anak perempuan, buku untuk anak laki-laki juga terdapat 3 sub materi yaitu (1) apa itu pubertas?, (2) apa mimpi basah itu?, (3) dampak apa yang muncul ketika masa pubertas?.

Pada panduan pelaksanaan layanan bimbingan informasi "menghadapi perubahan masa pubertas" berisikan (1) kata pengantar; (2) daftar isi; (3) daftar tabel; (4) daftar lampiran; (5) bagian 1: pendahuluan; (6) bagian 2: materi masa pubertas; (7) bagian 3: petunjuk pelaksanaan; (8) bagian 4: prosedur pelaksanaan; (9) bagian 5: evaluasi; (10) penutup; (11) daftar rujukan; (12) lampiran. Panduan ini digunakan oleh guru pembimbing sebagai petunjuk atau rambu-rambu ketika melaksanakan layanan bimbingan menghadapi perubahan masa pubertas. 
Berdasarkan hasil penilaian oleh ahli materi Bimbingan dan Konseling pada buku materi "menghadapi perubahan masa pubertas" untuk aspek ketepatan semua butir pernyataan memperoleh penilaian skala 3 artinya cukup tepat. Pada aspek kegunaan semua butir pernyataan memperoleh penilaian skala 3 artinya cukup berguna. Pada aspek kemudahan semua butir pernyataan masuk pada penilaian skala 3 artinya cukup mudah. Pada aspek kemenarikan semua butir memperoleh penilaian skala 3 artinya cukup menarik. Selain buku materi berikut hasil penilaian panduan pelaksanaan layanan bimbingan informasi "menghadapi perubahan masa pubertas" oleh ahli materi Bimbingan dan Konseling untuk aspek ketepatan semua butir pernyataan memperoleh penilaian skala 3 artinya cukup tepat. Pada aspek kegunaan semua butir pernyataan mendapat penilaian skala 3 artinya cukup berguna. Pada aspek kemudahan semua butir pernyataan mendapat penilaian skala 3 artinya cukup mudah. Pada aspek kemenarikan semua butir pernyataan mendapat penilaian skala 3 artinya cukup menarik. Dapat disimpulkan berdasarkan penilaian oleh ahli materi Bimbingan dan Konseling media layanan informasi "menghadapi perubahan masa pubertas" berupa buku materi dan panduan pelaksanaan layanan diperoleh tingkat keberterimaan cukup tepat, cukup berguna, cukup mudah dan cukup menarik untuk diberikan kepada siswa SD kelas tinggi.

Hasil penilaian buku materi "menghadapi perubahan masa pubertas" oleh ahli media pembelajaran, pada aspek ketepatan tujuh butir pernyataan mendapat penilaian skala 4 artinya sangat tepat. Satu butir pernyataan yaitu ketepatan font dan ukuran huruf pada sampul mendapat penilaian skala 3 artinya cukup tepat. Pada aspek kegunaan terdapat satu butir pernyataan yaitu kegunaan variasi font sebagai penekanan dan pembeda materi memperoleh penilaian skala 3 yang artinya cukup berguna. Sementara butir pernyataan aspek kegunaan lainnya mendapat penilaian skala 4 artinya sangat berguna. Pada aspek kemudahan semua butir pernyataan memperoleh penilaian skala 4 artinya sangat mudah. Pada aspek kemenarikan semua butir pernyataan memperoleh penilaian skala 4 artinya sangat menarik. Hasil penilaian panduan pelaksanaan layanan bimbingan informasi "menghadapi perubahan masa pubertas" semua butir pernyataan mendapat penilaian skala 4 artinya sangat tepat. Pada aspek kegunaan semua butir pernyataan mendapat penilaian skala 4 artinya sangat berguna. Pada aspek kemudahan semua butir pernyataan mendapat penilaian skala 4 artinya sangat mudah. Pada aspek kemenarikan semua butir pernyataan mendapat penilaian skala 4 artinya sangat menarik. Dapat disimpulkan berdasarkan penilaian ahli media pembelajaran untuk media layanan informasi "menghadapi perubahan masa pubertas" diperoleh tingkat keberterimaan sangat tepat, sangat berguna, sangat mudah dan sangat menarik untuk diberikan kepada siswa SD kelas tinggi.

Pendapat, saran dan masukan yang merupakan data kualitatif dari ahli (materi dan media) digunakan sebagai bahan revisi produk. Secara keseluruhan menurut ahli produk pengembangan sudah baik dan layak untuk digunakan. Saran dari ahli materi berkaitan dengan panduan yang berfokus pada bagian petunjuk pelaksanaan dan prosedur pelaksanaan. Sementara untuk masukan dari ahli media secara keseluruhan berkaitan dengan font atau jenis huruf yang digunakan pada media.

Setelah uji coba tahap pertama selesai dan telah dilakukan revisi. Selanjutnya uji coba tahap kedua dilakukan uji calon pengguna produk dan uji kelompok kecil. Berdasarkan penilaian buku materi "menghadapi perubahan masa pubertas" oleh calon pengguna produk didapat hasil kesepakatan calon pengguna untuk enam butir pernyataan aspek ketepatan masuk pada kategori sangat tinggi. Dua butir pernyataan lainnya masuk pada kategori cukup. Pada aspek kegunaan, kesepakatan calon pengguna lima butir pernyataan masuk pada kategori cukup dan tiga butir pernyataan masuk pada kategori sangat tinggi. Pada aspek kemudahan, kesepakatan calon pengguna lima butir pernyataan masuk pada kategori sangat tinggi dan satu butir pernyataan masuk pada kategori cukup. Pada aspek kemenarikan, kesepakatan calon pengguna produk dari tujuh butir pernyataan ada enam butir yang masuk kategori sangat tinggi dan satu butir pernyataan masuk kategori cukup. Selain buku materi, berikut hasil kesepakatan panduan pelaksanaan layanan bimbingan yaitu pada aspek ketepatan empat butir pernyataan masuk kategori cukup dan tiga butir pernyataan masuk kategori sangat tinggi. Pada aspek kegunaan lima butir pernyataan masuk kategori sangat tinggi 
dan satu butir pernyataan masuk kategori cukup. Pada aspek kemudahan lima butir pernyataan masuk kategori sangat tinggi dan satu butir pernyataan masuk kategori cukup. Pada aspek kemenarikan dua butir pernyataan masuk kategori cukup dan tiga butir pernyataan lainnya masuk kategori sangat tinggi. Berdasarkan penjabaran diatas uji calon pengguna produk diperoleh tingkat keberterimaan media layanan informasi "menghadapi perubahan masa pubertas" yaitu tepat, berguna, mudah dan menarik untuk diberikan kepada siswa SD kelas tinggi.

Berdasarkan pendapat, masukan dan saran dari calon pengguna produk, buku materi sudah sesuai harapan dan dapat dipahami oleh peserta didik. Hal yang perlu diperhatikan berkaitan dengan penulisan ejaan kata dan penggunaan kata yang beberapa masih cukup sulit untuk dipahami bagi siswa SD kelas tinggi.

Uji coba selanjutnya dilakukan dengan melibatkan siswa melalui uji kelompok kecil. Hasil penilaian buku materi "menghadapi perubahan masa pubertas" dalam uji kelompok kecil pada aspek ketepatan semua butir pernyataannya masuk dalam kategori intepretasi sangat tepat. Pada aspek kegunaan dari enam butir pernyataan terdapat satu butir pernyataan masuk dalam kategori intepretasi cukup berguna dan lima butir pernyataan lainnya masuk dalam kategori intepretasi sangat berguna. Pada aspek kemudahan semua butir pernyataan masuk dalam kategori intepretasi sangat mudah. Pada aspek kemenarikan semua butir pernyataan masuk dalam kategori intepretasi sangat menarik. Berdasarkan dari penjabaran diatas dapat disimpulkan bahwa buku materi "menghadapi perubahan masa pubertas" dapat diterima dan digunakan oleh siswa SD kelas tinggi.

Pada proses uji kelompok kecil siswa juga memberikan pendapat, masukan dan saran terhadap produk. Menurut siswa media yang dikembangkan menarik dan mudah dipahami. Selain itu melalui media yang dikembangkan berupa buku materi ini mereka merasa mudah dalam belajar khususnya terkait dengan materi perubahan masa pubertas. Hal ini berarti produk media layanan informasi "menghadapi perubahan masa pubertas" telah dapat digunakan dan tidak perlu mengalami revisi pada uji kelompok kecil. Setelah melalui semua tahap uji coba produk maka produk yang dihasilkan diperoleh tingkat keberterimaan tepat, berguna, mudah dan menarik.

\section{PEMBAHASAN}

Media yang dikembangkan ini berisikan informasi tentang menghadapi perubahan masa pubertas. Pada media ini disajikan informasi berkaitan dengan perubahan masa pubertas dan cara menghadapi perubahan masa pubertas. Selain media buku materi dalam pengembangan ini juga dihasilkan panduan pelaksanaan layanan bimbingan informasi "menghadapi perubahan masa pubertas". Panduan ini digunakan oleh guru pembimbing sebagai rambu-rambu dalam proses pelaksanaan layanan informasi menghadapi perubahan masa pubertas.

Materi yang disajikan dalam media layanan informasi ini telah didasarkan pada analisis kebutuhan. Selain itu pengembang juga melakukan studi literatur sebelum pengembangan ini dilaksanakan. Agar materi yang disajikan dalam produk sesuai dengan kebutuhan dan karakteristik siswa SD kelas tinggi. Hal ini sesuai dengan tahap awal desain penelitian pengembangan menurut Borg and Gall (1989) yaitu melakukan analisis kebutuhan.

Pengembangan buku materi ini dinilai berguna sebagai media untuk menyampaikan informasi. Hal ini sesuai dengan pernyataan Nursalim (2010) yang menyatakan pada intinya penggunaan media merupakan sarana bantu untuk mewujudkan situasi bimbingan dan konseling yang lebih efektif.

Materi yang disajikan yaitu menghadapi perubahan masa pubertas untuk siswa SD kelas tinggi dinilai sangat baik dan layak oleh ahli dan calon pengguna produk. Hal ini sebab rata-rata usia siswa SD kelas tinggi 10-13 tahun. Menurut Hurlock (1980), periode masa pubertas anak perempuan usianya berkisar antara 11-15 tahun, sedangkan anak laki-laki berkisar usia 12-16 tahun. Sehingga berdasarkan penjabaran tersebut maka materi perubahan masa pubertas dinilai tepat dan sesuai diberikan untuk siswa SD kelas tinggi karena mereka berada dalam rentang usia masa pubertas. Namun, pada kenyataan di lapangan terdapat pro dan kontra dimana pihak tertentu 
menganggap informasi ini masih tabu dan tidak layak diberikan untuk anak usia sekolah dasar. Hal ini dikarenakan siswa SD masih terlalu dini untuk mendapatkan informasi tersebut.

Panduan pelaksanaan layanan bimbingan informasi "menghadapi perubahan masa pubertas" menjelaskan tentang rambu-rambu pelaksanaan bimbingan yang harus dilakukan oleh guru pembimbing ketika menyampaikan informasi. Menurut Widada (1991) dalam menyampaikan informasi kepada siswa ada beberapa kemungkinan media yang digunakan konselor (guru pembimbing) salah satunya adalah konselor menggunakan media tetapi konselor tetap aktif hadir. Kehadiran konselor (guru pembimbing) untuk memberikan penjelasan lebih lanjut kepada siswa berkaitan dengan materi yang disajikan dalam media. Oleh sebab itu panduan ini disusun untuk melengkapi adanya buku materi "menghadapi perubahan masa pubertas" dalam kegiatan layanan bimbingan informasi bagi siswa SD kelas tinggi.

Media yang dikembangkan ini memiliki beberapa kelebihan yaitu (1) produk yang dikembangkan berdasarkan hasil analisis kebutuhan yang telah dilakukan; (2) produk telah melalui tahap uji coba kepada ahli, calon pengguna produk dan siswa (kelompok kecil); (3) panduan pelaksanaan layanan bimbingan dapat digunakan guru pembimbing sebagai rambu-rambu dalam memberikan layanan bimbingan. Sedangkan kelemahan produk pengembangan ini adalah materi menghadapi perubahan masa pubertas masih dianggap kurang pantas diberikan untuk siswa sekolah dasar karena dianggap masih terlalu dini.

\section{SIMPULAN}

Pengembangan ini menghasilkan produk media layanan informasi "menghadapi perubahan masa pubertas" berupa buku materi dan panduan pelaksanaan layanan bimbingan. Produk pengembangan ini telah melalui proses secara sistematis mulai dari melakukan analisis kebutuhan, perencanaan pengembangan, pengembangan media layanan informasi, melakukan uji coba produk oleh ahli materi, ahli media, calon pengguna produk dan kelompok kecil. Ketika proses uji coba produk juga dilakukan revisi yang didasarkan pada masukan dan saran sehingga produk dapat berterima secara teoritis dan praktis.

Berdasarkan hasil penelitian saran ditujukan kepada: (1) jurusan Bimbingan dan Konseling hendaknya dapat menggunakan produk pengembangan sebagai contoh media layanan informasi pada mata kuliah media BK dan teknik BK TK/SD; (2) guru hendaknya benar-benar mempelajari dan memahami media layanan informasi "menghadapi perubahan masa pubertas" sebelum memberikan layanan bimbingan; (3) peneliti selanjutnya disarankan menilai keefektifan media layanan informasi "menghadapi perubahan masa pubertas".

\section{DAFTAR RUJUKAN}

Borg, W.R \& Gall, M.D. 1989. Educational Research an Introduction fourth edition. New York: Longman Inc

Hurlock, E.B. 1980. Psikologi Perkembangan Suatu Pendekatan Sepanjang Rentang Kehidupan (Ridwan M.S, Ed.). Jakarta: Erlangga.

Handarini, D. M. 2000. Pengembangan Model Pelatihan Keterampilan Sosial Bagi Siswa Menengah Umum Terpadu. Disertasi tidak diterbitkan. Malang: FPS UM

Janiwarty, B. \& Pieter, H.Z. 2013. Pendidikan Psikologi untuk Bidan Suatu Teori dan Terapannya. Yogyakarta: Andi Offset

Prayitno \& Amti, E. 2004. Dasar-dasar Bimbingan dan Konseling. Jakarta: Rineka Cipta

Peraturan Menteri Pendidikan dan Kebudayaan Republik Indonesia Nomor 111 Tahun 2014 tentang Bimbingan dan Konseling pada Pendidikan Dasar dan Pendidikan Menengah. (Online), (https://akhmadsudrajat.files.wordpress.com/2014/11/permendikbudno-111-tahun-2014-tentang-bimbingan-dan-konseling.pdf), diakses 2015 
Simamora, Roymond H. 2009. Buku Ajar Pendidikan dalam Keperawatan. Bandung: EGC Penerbit buku kedokteran.

Sukmadinata, N.S. 2015. Metode Penelitian Penddikan. Bandung: PT Remaja Rosdakarya Irhami, M \& Wiyani, N.A. 2014. Bimbingan \& Konseling Teori dan Aplikasi di Sekolah Dasar. Yogyakarta: Ar-Ruzz Media.

Nursalim, Mochamad \& Mustaji. 2010. Media Bimbingan dan Konseling. Surabaya: Penerbit Unesa University Press

Nurihsan, A.J. 2006. Bimbingan dan Konseling dalam Berbagai Latar Belakang. Bandung: Refika Aditama

Universitas Negeri Malang. 2010. Pedoman Penulisan Karya Ilmiah edisi kelima. Malang: UM Press

Widada. 1991. Layanan Bimbingan dan Konseling di Sekolah. Malang:Depdikbud IKIP Malang 